\title{
Sprawozdanie z 34. Zjazdu Europejskiego Towarzystwa Chirurgii Onkologicznej w Liverpoolu
}

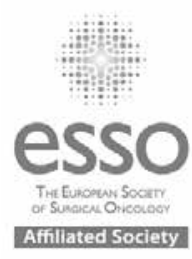

W dniach 29-31 października 2014 r. w Liverpoolu przebywali chirurdzy onkolodzy, uczestniczący w 34. Kongresie Europejskiego Towarzystwa Chirurgii Onkologicznej (European Society of Surgical Oncology; ESSO). Liczba delegatów osiągnęła 1000 osób, reprezentujących głównie kraje europejskie, ale cześć uczestników pochodziła z Azji. Liczba uczestników z Polski przekroczyła 30 osób. W czasie otwarcia Zjazdu uhonorowano nagrodą za całokształt dokonań prof. L. Blumgarta, zaś nagrodę im. Ronalda Ravena otrzymał prof. C. Balch. Tytuł członka honorowego ESSO otrzymał prof. Theo Wiggers, który jest organizatorem i wykładowcą ESO-ESSO Masterclass on Colorectal Cancer Surgery w Warszawie w dniach 7-12 marca 2015 r.

W programie naukowym Zjazdu znalazło się kilkadziesiąt sesji, toczących się równolegle w 6 salach. Wiele czasu poświęcono leczeniu pierwotnych i wtórnych nowotworów wątroby, w tym także - m.in. - kontrowersyjnej roli przeszczepienia wątroby z takich wskazań. W programie znalazły się także prezentacje typu state of art, dotyczące złożonych sytuacji klinicznych, takich jak: nawrót nowotworu złośliwego zlokalizowany w miednicy, rozsiew wewnątrzotrzewnowy, leczenie okołooperacyjne i operacyjne chorych na raka żołądka, przeprowadzone z dużym udziałem przedstawicieli japońskiej chirurgii onkologicznej. Szczegółowy program naukowy jest dostępny na stronie internetowej www.essoweb.org.

W sesjach, podczas których przedstawiono prace wybrane przez komitet naukowy do prezentacji ustnych, należy wymienić doniesienia z Polski: Zieliński i wsp. (The significance of fiberoptic ductoscopy in patients with pathological nipple discharge in one single centre material), Polkowski i wsp. (Local recurrence and not liver or peritoneal colorectal carcinoma relapse has the worst prognosis when treated by multimodality approach), Zdzienicki i wsp. (The long-term results of sentinel node biopsy with triple-technique in cutaneous melanoma), Kurylcio i wsp. (Sentinel node biopsy with superparamagnetic iron oxide versus radioisotope technique in breast cancer patients - initial experience from two Polish centres), Nowacki i wsp. (CDDP filled carbon nanotubes may inhibit cancer recurrence - animal model nephron sparing surgery study). Wśród prezentacji wideo znalazła się praca przygotowana w Hiszpanii przez polskich chirurgów (Down-to-up transanal total mesorectal excision). Ponadto wśród prac zakwalifikowanych do prezentacji plakatowych było 14 pochodzących z Polski. Doniesienie autorstwa Murawy, Nowaczyka (Influence of micrometastasis in sentinel lymph nodes in colon cancer on prognosis and survival) zdobyło III nagrodę (Bronze Award). Ponadto plakaty autorstwa Kołacińskiej i wsp. (Immune checkpoints in breast cancer surgery) oraz Mielko i wsp. (Postoperative complications of the abdomino-sacral amputation of the rectum for low rectal carcinoma:Multicentre Polish experience) zostały wyróżnione jako top scoring abstracts.

Na uwagę zasługuje fakt, że przedstawiciele PTChO działający w strukturach ESSO (W. Polkowski oraz D. Murawa) przewodniczyli 4 sesjom w trakcie Zjazdu w Liverpoolu. Odzwierciedla to ciągły rozwój kontaktów pomiędzy PTChO i ESSO oraz uznanie dla polskiego środowiska ze strony władz europejskiego Towarzystwa. Nie ulega wątpliwości, że polska chirurgia onkologiczna odgrywa wiodącą rolę w regionie Europy Środkowo-Wschodniej.

W czasie Zjazdu odbyło się Walne Zgromadzenie ESSO, w którym wybrano nowe władze Towarzystwa. Prof. Graeme Poston ustąpił z funkcji prezesa, zaś stanowisko to objął prof. Riccardo Audisio. Nowym prezesem-elektem został prof. Santiago Gonzalez Moreno. W zarządzie ESSO przewodniczącym Website \& Editorial Committee został prof. Wojciech Polkowski. Członkiem zarządu wybrano ponadto dr hab. 


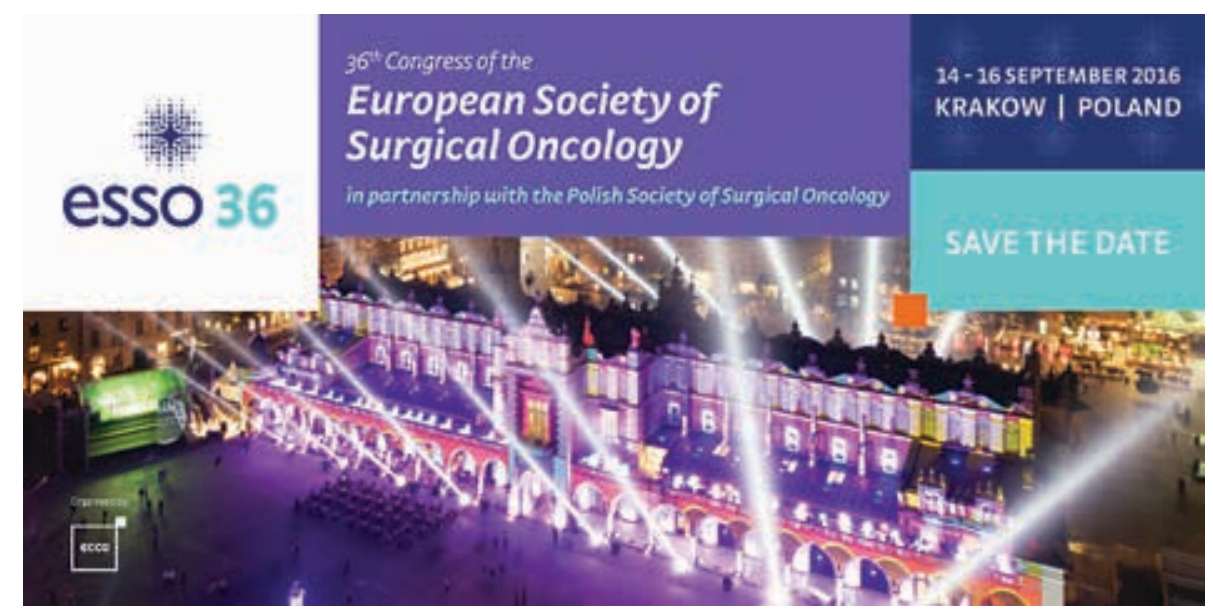

Agnieszkę Kołacińską, zaś dr Wojciech M. Wysocki został członkiem Membership Executive Committee. Na kolejną kadencję do Educational \& Training Committee wybrano dr. hab. Dawida Murawę. W zarządzie stowarzyszenia młodych chirurgów onkologów (EYSAC) nadal zasiadać będzie dr Karol Połom.

W czasie Zjazdu odbyło się spotkanie Memebership Advisory Committee, na którym przedstawiono m.in. oczekiwania narodowych towarzystw wobec ESSO. Ze strony polskiej przedstawiciele Zarządu PTChO przedstawili postulaty dotyczące m.in. zwiększenia liczby kursów organizowanych przez ESSO w Europie Środkowej, a także opcjonalnego rozszerzenia polskiego egzaminu specjalizacyjnego z chirurgii onkologicznej o moduł pozwalający jednocześnie uzyskać europejski certyfikat umiejętności z zakresu chirurgii onkologicznej (ESSO/EBSQ/UEMS). Dr hab. Agnieszka Kołacińska była egzaminatorem Europejskiego Egzaminu w zakresie Chirurgii Piersi (European Board of Surgery Qualification in Breast Surgery), który odbył się bezpośrednio po zakończeniu Kongresu.

W czasie spotkania Educational \& Training Committee omówiono organizację kursów ESSO w 2015 roku. Przedstawiona przez D. Murawę propozycja organizacji kursu na temat leczenia nowotworów górnego odcinka przewodu pokarmowego spotkała się z pełną aprobatą. Po dyskusji i prezentacji założeń programowych zdecydowano, że kurs odbędzie się bezpośrednio przed Zjazdem PTCHO w Poznaniu (tj. 20-21 maja 2015 r.). Komitetowi Naukowemu przewodniczyć będzie prof. Franco Roviello.

W czasie tegorocznego Kongresu wielokrotnie informowano delegatów, że 36. Zjazd ESSO odbędzie się w dniach 14-16 września 2016 r. w Krakowie. Zjazd Polskiego Towarzystwa Chirurgii Onkologicznej w 2016 roku także odbędzie się w Krakowie, w bezpośredniej łączności ze Zjazdem ESSO. Program tego wydarzenia zostanie przygotowany przez zarządy obu Towarzystw. W Liverpoolu, z udziałem prof. K. Hermana, prof. W. Polkowskiego oraz dr. W.M. Wysockiego, odbyły się pierwsze szczegółowe rozmowy na ten temat.

\section{Dr n. med. Wojciech M. Wysocki}

Centrum Onkologii — Instytut im. Marii Skłodowskiej-Curie, Oddział w Krakowie

Doc. dr hab. n. med. Dawid Murawa

Wielkopolskie Centrum Onkologii w Poznaniu

Dr hab. n. med. Agnieszka Kołacińska

Regionalny Ośrodek Onkologiczny w Łodzi

Prof. dr hab. n. med. Wojciech Polkowski

Uniwersytet Medyczny w Lublinie 